\title{
O ser humano: luz e sombra
}

The human being: light and shade

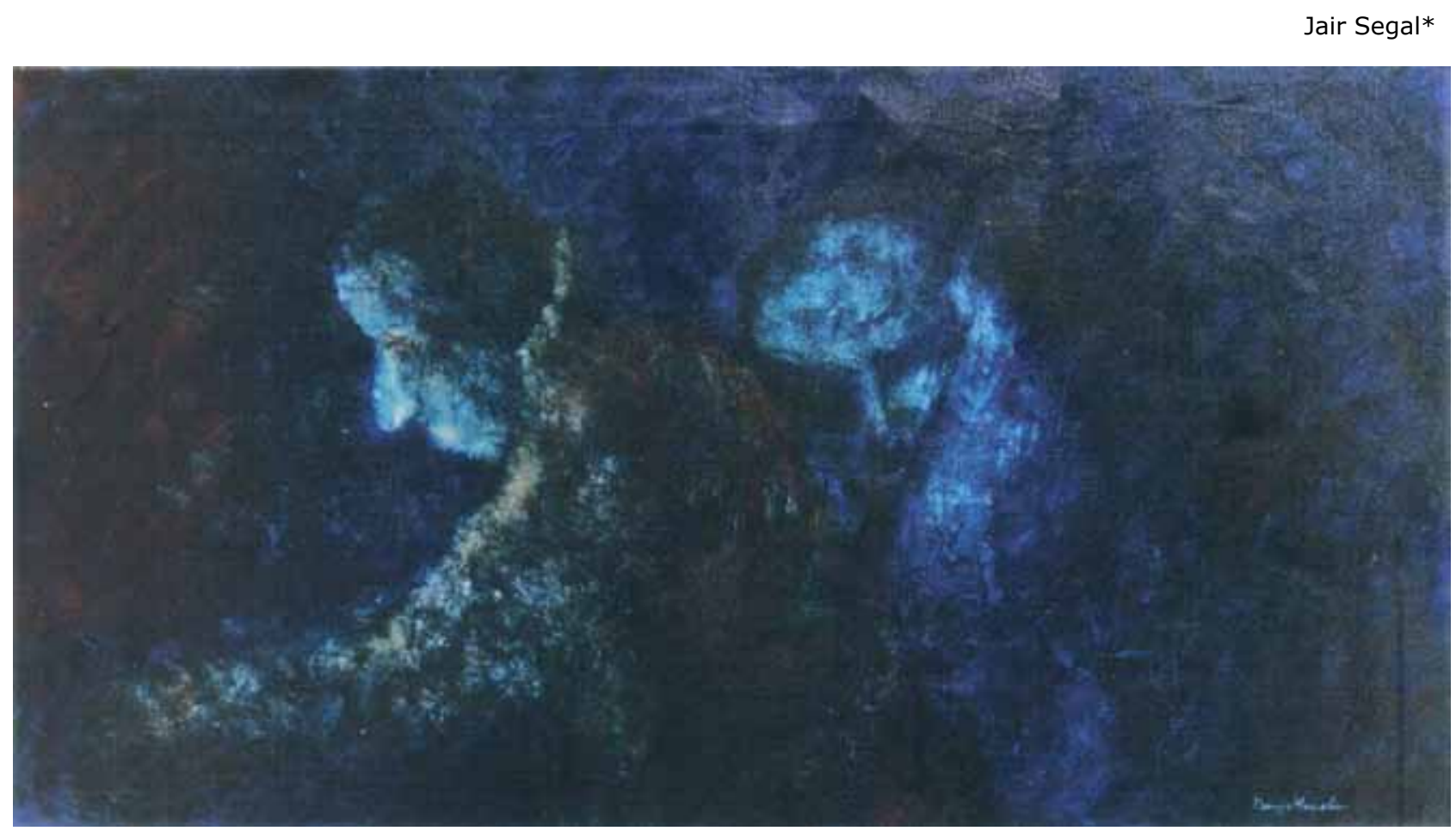

Denise Marcolin, Aconchego, 1992, acrílico sobre tela, 64 × $140 \mathrm{~cm}$.

"No exercício da tinta sobre a tela me proponho estetizar o cotidiano nos seus mais singulares detalhes. Movimentos expressos em cores vibrantes fazem surgir imagens, até as imperceptíveis. Linhas e manchas constituem corpos. Contornos irregulares e imprecisos indicam trajetórias inesperadas. Para mim, arte é expressão da vida e com isso importa afetar pela sensação." Com essas palavras a artista plástica gaúcha Denise Marcolin define suas obras em pintura com técnica acrílica, onde se visualizam diferentes texturas e transparências.

A escolha de seu trabalho para ilustrar a capa deste primeiro número da revista Trends in Psychiatry and Psychotherapy se deve, principalmente, às características de sua obra. Ao nos depararmos com o trabalho de Denise, observamos uma intensidade de cores e traços, com uma marcante expressividade. Percebemos, com variadas formas de sentimento, os elementos que vão sendo "revelados" através de luz e sombra, em diferentes camadas de tinta, refletindo cenas do nosso cotidiano. São homens e mulheres comuns, percebidos pelos nossos sentidos ou imaginação, que retratam de forma vibrante o sentimento humano, seja qual ele for, gerando e refletindo a nossa emoção.

A comunicação de sentimentos e emoções também é o nosso cotidiano enquanto psiquiatras. Sua tradução depende da nossa capacidade de sentir, perceber e compreender aquilo que nossos pacientes expressam. Denise Marcolin nos transmite, através de sua arte, a experiência humana de uma forma inquietante e provocativa. Com uma linguagem direta, ela comunica de várias maneiras sentimentos e emoções.

* Diretor científico, APRS, e editor associado, Trends in Psychiatry and Psychotherapy.

Como citar: Segal J. O ser humano: luz e sombra. Trends Psychiatry Psychother. 2011;33(3):131-2. 


\section{Currículo}

Denise Marcolin é pintora, nascida em Gaurama (RS), no ano de 1959. É licenciada em Educação Artística e bacharel em Desenho e Plástica pela Universidade de Passo Fundo (UPF), em Passo Fundo (RS). Frequentou o Atelier Livre e fez aula com Armando Almeida e Paulo Porcella. Estudou pintura e desenho com Berenice Unikowski e Fernando Baril. Desde 1982, vem participando de diversas exposições coletivas em Salões de Arte em Santa Maria, Rio Grande, Porto Alegre, Santo Ângelo, Cruz Alta, Santa Rosa, Passo Fundo (todas no RS), Blumenau (SC) e São Paulo (SP). Foi classificada entre as 100 meIhores obras do país no $1^{\circ}$ Prêmio Pirelli Pintura Jovem/ MASP, em 1983. Realizou exposições individuais no Mu- seu de Artes Visuais Ruth Schneider, em Passo Fundo (RS), na Sala José Antônio Teodoro da Casa de Cultura de Londrina (PR), na Casa de Cultura Percy Vargas, em Caxias do Sul (RS), no Centro Cultural Klinger Filho, em Porto Alegre (RS), no Salão de Artes de Novo Hamburgo (RS) e na Gravura Galeria de Arte, também em Porto Alegre (RS). Fez Especialização em Museologia e Patrimônio Cultural na Universidade Federal do Rio Grande do Sul (UFRGS) em 2005. Suas obras podem ser vistas em acervos de diversas cidades do Rio Grande do Sul. Atualmente, mantém em sua residência um ateliê onde desenvolve sua atividade como pintora e ministra aulas de desenho e pintura. 